\title{
DOCETAXEL HIDRAT MENGHAMBAT PROLIFERASI DAN METASTASIS SEL KANKER ORAL SP-C1 MELALUI INDUKSI PROTEIN MASPIN
}

\author{
Supriatno \\ Bedah Oral Maksilofasial dan Onkologi, departemen Oral Medicine, \\ Fakultas Kedokteran Gigi UGM, Yogyakarta
}

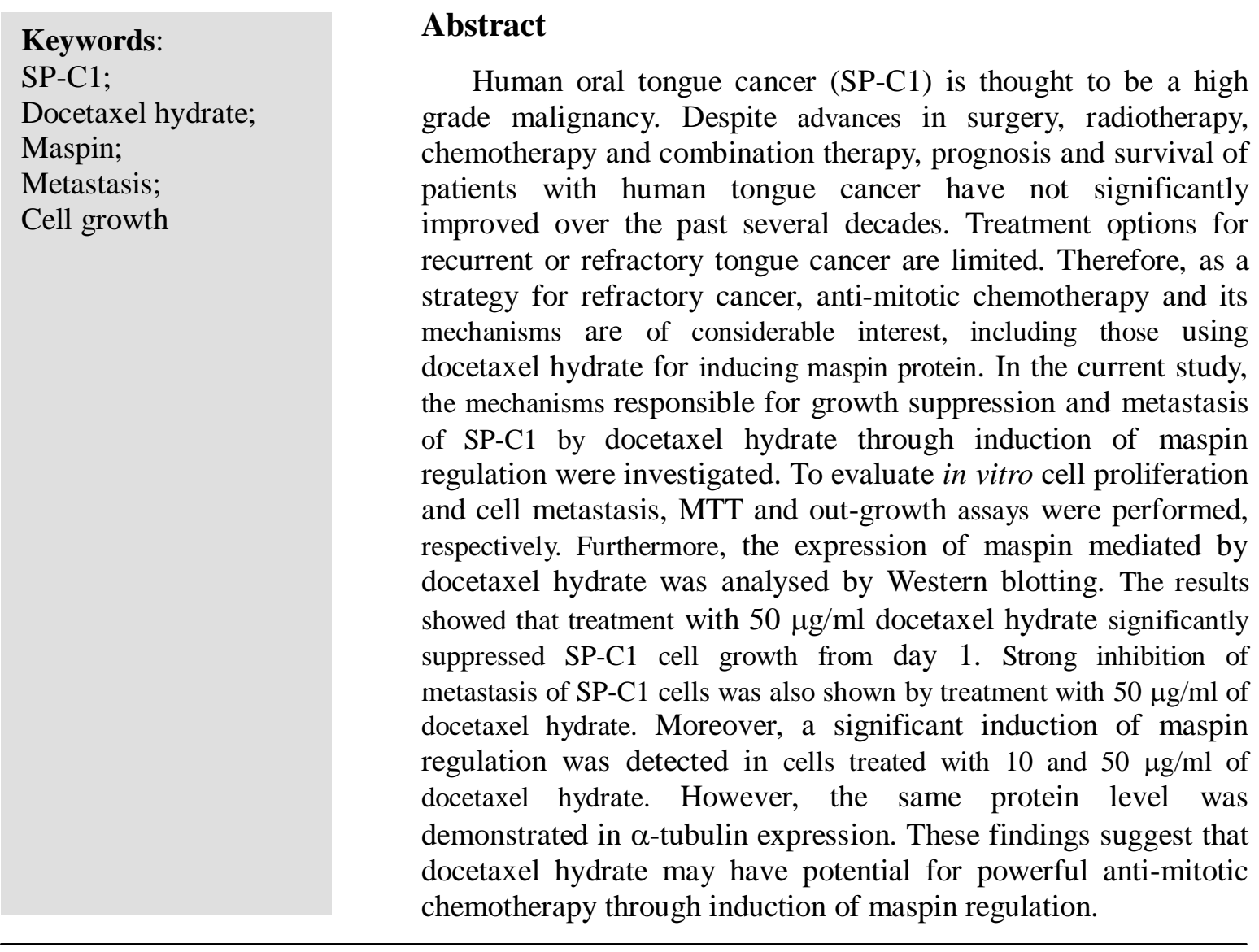




\section{Pendahuluan}

Kanker oral (oral squamous cell carcinoma $=$ OSCC) merupakan neoplasma leher dan kepala yang banyak terjadi, mempunyai angka morbiditas dan mortalitas tinggi serta prognosis buruk. ${ }^{1}$ OSCC mempunyai invasi lokal dan metastasis regional yang tinggi ke limfonodi regional, dan sering menyebabkan rekurensi lokal setelah pembedahan radikal akibat terjadinya mikroinvasi dan/atau mikro metastasis sel dari lesi primer. ${ }^{2}$ Walaupun pembedahan merupakan pilihan utama, penderita kanker yang mengalami rekurensi atau metastasis yang telah menyebar ke organ tubuh lain tidak dianjurkan untuk dilakukan pembedahan. ${ }^{3}$ Prognosis kasus OSCC ini tidak berubah secara signifikan dalam 10 tahun terakhir, ${ }^{4}$ dan rerata pertahanan hidup (survival rate) tidak berubah selama 2 dekade terakhir. ${ }^{5}$ Patogenesis molekuler tipe OSCC ini masih belum diketahui dengan jelas. Beberapa peneliti melaporkan bahwa tingginya frekuensi mutasi gen p53 pada kanker leher dan kepala menyebabkan meningkatnya pertumbuhan sel kanker. ${ }^{6,7}$ Selain itu, timbulnya onkogen lain seperti EGFR, ${ }^{8}$ cmyc, ${ }^{9}$ dan bcl- ${ }^{10}$ dilaporkan sebagai penyebab pertumbuhan sel kanker. Berdasarkan laporan tersebut dapat diketahui bahwa penyebab pertumbuhan sel kanker masih belum jelas. Untuk itu diperlukan penelitian kontinyu untuk meningkatkan kemampuan perawatan yang lebih efektif dan efisien terhadap sel kanker OSCC, salah satunya menggunakan docetaxel hidrat untuk meningkatkan ekspresi protein maspin.

Maspin adalah protein sitoplasma dengan berat molekul $42 \mathrm{kDa}$ yang merupakan protease inhibitor dari famili serpin. Maspin terekspresi pada sel epitel normal mamae manusia ${ }^{11}$ dan berhubungan dengan sekresi vesikel serta permukaan seluler. ${ }^{2}$ Maspin diketahui juga mempunyai kemampuan sebagai penghambat tumor. ${ }^{13}$ Transfeksi sel karsinoma mamae manusia menggunakan gen maspin diketahui dapat menurunkan induksi tumor, metastasis dan invasi sel. ${ }^{11}$ Maspin dapat pula menurunkan regulasi kanker mamae, dan ekspresinya dapat menghambat metastasis. Penurunan ekspresi maspin ini kemungkinan disebabkan tidak adanya transaktivasi melalui elemen Ets dan
Ap1 pada maspin promoter ${ }^{14}$ atau menurunnya regulasi transkripsi. ${ }^{15}$ Mutasi maspin terjadi pada asam amino 319 yang merubah isoleucine menjadi valin. ${ }^{15} \quad$ Single-chain tissue plasminogen activator (tPA) berinteraksi spesifik dengan peptid loop reaktif maspin dan dengan bentuk komplek rekombinan maspin yang stabil sehingga menyebabkan efek hambatan pada tPA. ${ }^{16}$ Walaupun menurunnya regulasi maspin telah diketahui meningkatkan progresivitas sel kanker mamae ${ }^{11}$ dan prostat, ${ }^{15}$ aktivitas antitumor maspin pada sel kanker oral belum diketahui dengan jelas.

Docetaxel hidrat (Taxotere) merupakan agen kemoterapi anti-mitotik yang diekstrak dari tanaman Taxus brevifolia. ${ }^{17}$ Agen tersebut sudah banyak digunakan di klinik untuk perawatan beberapa jenis kanker manusia. Docetaxel hidrat meningkatkan aktivitas sitotoksik sel kanker payudara, ovarian, prostat, colorektal, gastrik, renal dan non-small cell kanker paru. ${ }^{18}$ Target molekuler docetaxel hidrat adalah mengikat mikrotubulus dengan afinitas tinggi. Docetaxel diketahui mempunyai konsentrasi yang lebih tinggi pada sel adenokarsinoma ovarium dibandingkan pada sel karsinoma ginjal. Hal ini mengindikasikan bahwa perawatan kanker ovarium menggunakan docetaxel lebih efektif. ${ }^{19}$ Docetaxel dilaporkan menginduksi fosforilasi oncoprotein bcl-2 yang meningkatkan apoptosis. ${ }^{18}$

Tujuan penelitian ini adalah menganalisis mekanisme hambatan proliferasi dan metastasis sel kanker SP-C1 menggunakan docetaxel hidrat melalui induksi regulasi maspin.

\section{Bahan dan Cara Kerja}

\section{Sel dan kultur sel}

Sel kanker SP-C1 diisolasi dari penderita kanker lidah. Sel dibiakkan dalam cawan Petri (Falcon, Becton Dickinson Labware, Lincoln Park, NJ, USA) menggunakan media Dulbecco's modified Eagle medium (DMEM, Sigma, St Louis, MO, USA) ditambah dengan fetal calf serum 10\% (FCS, Moregate BioTech, Bulimba, Australia), streptomisin $100 \mu \mathrm{g} / \mathrm{ml}$ dan penisilin 100 unit/ml (Gibco, Grand Island, 
NY, USA). Sel diinkubasi dengan kelembaban udara $95 \%$ dan $\mathrm{CO}_{2} 5 \%$ pada suhu $37^{\circ} \mathrm{C}$, dan diperbanyak pada cawan petri baru sebelum sel kanker penuh. ${ }^{1}$

\section{Uji hambatan pertumbuhan sel (MTT assay)}

Docetaxel hidrat (Aventis Pharma Co., Ltd, Japan) dilarutkan dalam medium DMEM. Efek docetaxel hdrat dievaluasi secara in vitro untuk mengetahui proliferasi sel SP-C1 dengan menggunakan [3-(3,4-dimethyl-thiazol-2-yl)2,5-diphenyltetra zolium bromide] (Sigma, Chemical Co., St.Louis, MO, USA). Sel (3 x $10^{3} \mathrm{sel} /$ sumur) ditanam pada plat dengan 96 sumur (Falcon, Lincoln Park, NJ, USA) berisi DMEM ditambah FCS $10 \%$. Setelah diinkubasi selama 24 jam, dilakukan perawatan docetaxel hidrat dengan berbagai konsentrasi $(0,1,10$ dan $50 \mu \mathrm{g} / \mathrm{ml})$. Jumlah sel dihitung menggunakan BioRad Microplate Reader (BioRad Laboratories, CA, USA) dengan panjang gelombang $540 \mathrm{~nm}$ pada hari ke-1 dan 3.

\section{Uji metastasis (Out-growth assay)}

Sel SP-C1 dibiakkan pada cover glass 10 mm (Matsunami Ltd., Osaka, Japan). Cover glass diletakkan di tengah cawan Petri berdiameter $60 \mathrm{~mm}$ dan media DMEM dengan berbagai konsentrasi docetaxel hidrat ditambahkan tanpa menggeser cover glass. Sel dibiakkan selama 10 hari dan diwarnai dengan larutan hematoksilin (Braidwood Lab, Sussex, UK) setelah fiksasi dengan $90 \%$ methanol (Wako Pure Chemical Industries, Japan).

\section{Ekspresi protein maspin dan $\alpha$-tubulin}

Deteksi protein maspin dan $\alpha$-tubulin dilakukan dengan analisis Western blotting. Sampel protein $(50 \mu \mathrm{g})$ dari sel SP-C1 yang diperlakukan dengan docetaxel hidrat selama 72 jam dielektroforesis menggunakan gel sodium dedoksil sulfat (SDS)-polyacrylamide dan ditransfer ke membran nitroselulose (PVDF membrane; BioRad, Hercules, CA, USA). Membran PVDF diblok dengan larutan TBS dalam $5 \%$ dry milk pada suhu $37^{\circ} \mathrm{C}$ selama 1 jam. Kemudian diinkubasi dengan anti-maspin rabbit polyclonal antibody dan anti- $\alpha$ tubulin
(Santa Cruz Biotechnology, CA, USA). Protein dideteksi menggunakan $\mathrm{ECL}^{\mathrm{TM}}$ plus (Amersham Pharmacia Biotech, Buckinghamshi re, UK).

\section{Analisis statistik}

Analisis statistik dilakukan dengan program Stat Work komputer Macintosh (Cricket Software, Philadelphia, PA, USA). Data dianalisis menggunakan Analisis varians (ANOVA) dua jalur dilanjutkan dengan Tukey's test (t-test) dengan derajat kemaknaan $95 \%$.

\section{Hasil Penelitian}

\section{Efek docetaxel hidrat terhadap sel SP-C1 in vitro}

Relatif jumlah sel dievaluasi dengan membandingkan absorben setiap sel menggunakan uji MTT pada hari ke-1 dan 3. Relatif jumlah sel SP-C1 yang diperlakukan dengan docetaxel $50 \mu \mathrm{g} / \mathrm{ml}$ pada hari ke-1 menunjukkan penurunan yang signifikan $(\mathrm{P}<$ $0,05)$, sedangkan hari ke-3 menampakkan bahwa hambatan pertumbuhan sel sangat kuat terjadi pada sel yang diperlakukan dengan docetaxel konsentrasi 10 dan $50 \mu \mathrm{g} / \mathrm{ml}$ dibandingkan dengan kontrol $(\mathrm{P}<0,01)$ (Gambar 1).

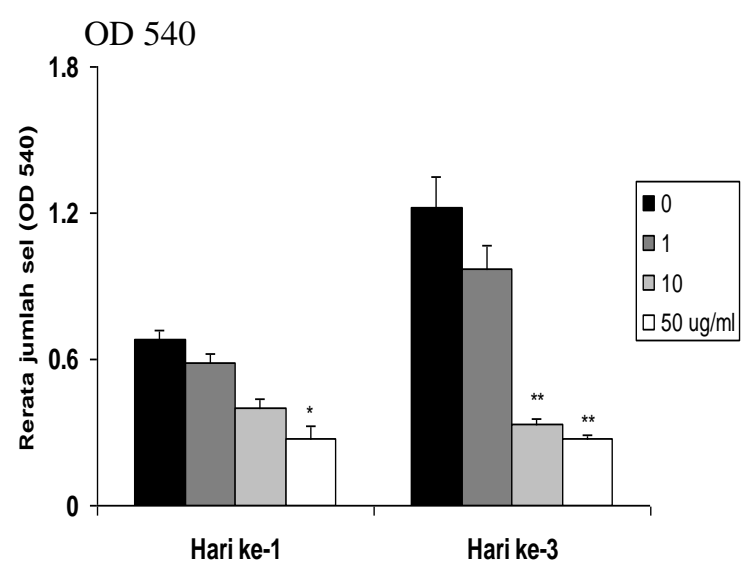

Gambar 1. Rerata jumlah sel SP-C1 yag diperlakukan dengan docetaxel hidrat berbagai konsentrasi pada hari ke-1 d an -3 dengan optical density (OD) 540. 


\section{Hambatan metastasis sel}

Hambatan metastasis sel SP-C1 dilakukan menggunakan out growth assay. Uji ini dikembangkan untuk menganalisis beberapa aspek biologi sel kanker, terutama kemampuan invasi dan metastasis. ${ }^{20}$ Sel SP-C1 yang diperlakukan dengan docetaxel $50 \mu \mathrm{g} / \mathrm{ml}$ mempunyai hambatan metastasis yang kuat dibandingkan dengan docetaxel $1 \mu \mathrm{g} / \mathrm{ml}$ atau kontrol (Gambar 2). Pada kontrol terlihat adanya pertumbuhan sel yang meluas dan keluar dari cover glass, sedangkan sel yang diperlakukan dengan docetaxel 1 sampai 50 $\mu \mathrm{g} / \mathrm{ml}$ mulai terlihat hambatan metastasis.

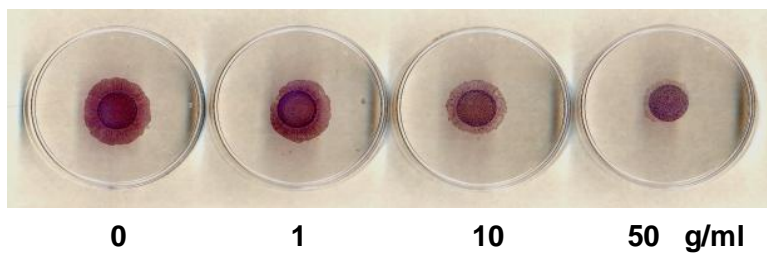

Gambar 2. Uji hambatan metastasis menggunakan out growth assay pada sel SP-C1 yang diperlakukan dengan docetaxel konsentrasi $0,1,10,50 \mu \mathrm{g} / \mathrm{ml}$.

\section{Analisis Western blotting}

Analisis Western blotting menunjukkan peningkatan regulasi protein Maspin $(42 \mathrm{kDa})$ pada sel SP-C1 yang diperlakukan dengan docetaxel dibandingkan kontrol, sedangkan ekspresi protein $\alpha$-tubulin sebagai kontrol positif terdeteksi mempunyai level protein yang sama pada setiap sampel SP-C1 yang diuji (Gambar 3). Peningkatan ekspresi protein Maspin menunjukkan bahwa agresivitas dan aktivitas sel kanker SP-C1 menurun.

\section{Docetaxel}

\begin{tabular}{|c|c|c|c|c|}
\hline 0 & 1 & 10 & 50 & $\mu \mathrm{g} / \mathrm{ml}$ \\
\hline enene & wien & clabey & 6hese & Maspin \\
\hline & & hent & nowere & $\alpha$-tubulin \\
\hline
\end{tabular}

Gambar 3. Ekspresi protein maspin dan $\alpha$ tubulin pada sel SP-C1 yang diperlakukan dengan docetaxel 0,1 , $10,50 \mu \mathrm{g} / \mathrm{ml}$.

\section{Diskusi}

Maspin (42 kDa) merupakan protein sitoplasma penghambat enzim protease pada beberapa jenis kanker manusia. Penelitian terdahulu melaporkan bahwa maspin mempunyai fungsi sebagai gen dan protein penghambat tumor yang dapat meningkatkan hambatan proliferasi, invasi, metastasis dan motilitas sel kanker. ${ }^{11,13,16}$ Tetapi, masih sangat sedikit dilaporkan hubungan tingkat ekspresi maspin terhadap kanker rongga mulut, terutama OSCC yang mempunyai frekuensi kejadian yang tinggi diantara kanker leher dan kepala, serta mempunyai tingkat invasi dan metastasis yang cepat ke limfonodi regional. Perawatan OSCC dikategorikan sebagai penyakit yang sukar perawatannya walaupun telah dilakukan pembedahan radikal. Hal ini disebabkan terjadinya mikro invasi dan/atau mikro metastasis dari lesi primer.

Pada penelitian ini, telah dilakukan isolasi sel SP-C1 dari penderita kanker lidah dengan diferensiasi sedang dan belum melibatkan jaringan otot. ${ }^{1,2}$ Hasil penelitian menggunakan analisis Western blotting pada sel SP-C1 menunjukkan bahwa ekspresi protein maspin meningkat pada sel yang dirawat dengan docetaxel, suatu kemoterapi anti-mitotik. Sebaliknya, ekspresi protein maspin menurun pada sel SP-C1 yang tidak dirawat. Hasil tersebut mendukung konsep bahwa maspin mempunyai fungsi sebagai penghambat tumor. Data ini menunjukkan pula bahwa pertumbuhan dan perkembangan OSCC melibatkan regulasi protein Maspin. Selanjutnya, hasil penelitian hambatan proliferasi sel SP-C1 menunjukkan bahwa docetaxel menghambat proliferasi sel SP-C1 dengan kuat. Data yang sama dilaporkan Rowinsky ${ }^{21}$ pada kanker ovarium, paru dan colon. Mekanisme hambatan docetaxel kemungkinan melibatkan c-Jun N-terminal kinase (JNK) atau stress-activated protein kinase (SAPK) yang dapat menyebabkan apoptosis. $^{22}$ Laporan lain menyatakan bahwa docetaxel mengaktifkan Raf-1 dan menyebabkan fosforilasi Bcl2 pada fase G2/M yang disertai apoptosis. ${ }^{23}$ Pada penelitian ini diketahui bahwa hambatan proliferasi sel kanker 
SP-C1 oleh docetaxel hydrate disebabkan meningkatnya regulasi protein maspin. Hasil ini mengindikasikan bahwa meningkatnya ekspresi protein maspin berhubungan dengan prognosis baik, pertahanan hidup tinggi, dan hambatan progresivitas sel kanker yang kuat. Sesuai dengan penelitian yang diharapkan, hambatan proliferasi sel dikonfirmasikan dengan hambatan metastasis sel SP-C1 melalui out growth assay. Pada sel kontrol diketahui bahwa sel tumbuh dan menyebar melewati gelas bundar diameter $10 \mathrm{~mm}$ setelah 10 hari inkubasi pada suhu $37^{\circ} \mathrm{C}$. Hambatan metastasis terlihat jelas pada sel SP-C1 yang diperlakukan dengan docetaxel hidrat konsentrasi $50 \mu \mathrm{g} / \mathrm{ml}$. Sel terhambat pertumbuhannya dan masih dalam gelas bundar. Warna sel tampak lebih muda menunjukkan sel yang tumbuh sedikit dibandingkan kontrol. Data tersebut berarti docetaxel hidrat efektif menghambat metastasis sel SP-C1 melalui induksi protein maspin.

Kesimpulan, docetaxel hidrat mempunyai kemampuan kemoterapi yang kuat pada sel kanker SP-C1 melalui peningkatan regulasi protein maspin.

\section{Ucapan terima kasih}

Ucapan terima kasih ditujukan kepada drg. Yuletnawati, mas Adit, mas Denta, dan dik Saka atas bantuan menyiapkan alat dan bahan penelitian, para co-ass di departemen Oral Medicine FKG UGM atas bantuannya menyelesaikan penelitian ini. Terima kasih kepada Monbusho, Japan yang telah mendanai penelitian ini.

\section{Bahan Acuan}

1. Supriatno, Harada K, Kawaguchi S, Yoshida $\mathrm{H}$ and Sato M: Effect of p27 $7^{\text {Kip1 }}$ on the ability of invasion and metastasis of an oral cancer cell line. Oncol Rep 2003; 10: 527-32.

2. Supriatno, Harada K, Hoque MO, Bando T, Yoshida $\mathrm{H}$ and Sato M: Overexpression of p2 $7^{\text {Kip1 }}$ induces growth arrest and apoptosis in an oral cancer cell line. Oral Oncol 2002; 38: 730-6.

3. Harada K, Supriatno, Yamamoto S,
Kawaguchi S, Yoshida $\mathrm{H}$ and Sato M: Cepharanthine exerts antitumor activity on oral squamous cell carcinoma cell lines by induction of $\mathrm{p} 27^{\mathrm{Kip} 1}$. Anticancer Res 2003; 23: $1441-8$.

4. Ammar A, Uchida D, Begum NM, Tomizuka Y, Iga H, Yoshida H, Sato M. The clinicopathological significance of the expression of CXCR4 protein in oral squamous cell carcinoma. Int J Oncol 2004; 25:65-71.

5. Lippman SM, Benner SE, Hong WK. Cancer chemoprevention. J Clin Oncol 1994; 12:851-73.

6. Ahomadegbe JC, Barrois M, Fogel S, Le Bihan ML, Douc-Rasy S, Duvillard P, Armand JP, Riou G. High incidence of p53 alterations (mutation, deletion, overexpression) in head and neck primary tumors and metastases; absence of correlation with clinical outcome. Frequent protein overexpression in normal epithelium and in early non-invasive lesions. Oncogene $1995 ; 10: 1217-27$.

7. Somers KD, Merrick MA, Lopez ME, Incognito LS, Schechter GL, Casey G. Frequent p53 mutations in head and neck cancer. Cancer Res 1992; 52:5997-6000.

8. Yamamoto T, Kamata N, Kawano H, Shimizu S, Kuroki T, Toyoshima K, Rikimaru K, Nomura N, Ishizaki R, Pastan I, Gamou S, Shimizu N. High incidence of amplification of the epidermal growth factor receptor gene in human squamous carcinoma cell lines. Cancer Res. 1986; 46:414-6

9. Field JK, Spandidos DA, Stell PM, Vaughan ED, Evan GI, Moore JP. Elevated expression of the c-myc oncoprotein correlates with poor prognosis in head and neck squamous cell carcinoma. Oncogene. 1989; 4:1463-8.

10. Berenson JR, Yang J, Mickel RA. Frequent amplification of the bcl-1 locus in head and neck squamous cell carcinomas. Oncogene. 1989; 4:1111-6.

11. Zou Z, Anisowicz A, Hendrix MJ, Thor A, Neveu M, Sheng S, Rafidi K, Seftor E, Sager R. Maspin, a serpin with tumorsuppressing activity in human mammary epithelial cells. Science 1994; 263:526-9.

12. Pemberton PA, Tipton AR, Pavloff N, Smith J, Erickson JR, Mouchabeck ZM, Kiefer MC. Maspin is an intracellular serpin that 
partitions into secretory vesicles and is present at the cell surface. J Histochem Cytochem 1997; 45: 1697-706.

13. Sager R, Sheng S, Pemberton P, Hendrix MJ. Maspin: a tumor suppressing serpin. Curr Top Microbiol Immunol 1996: 213:5164.

14. Zhang M, Magit D, Sager R. Expression of maspin in prostate cells is regulated by a positive ets element and a negative hormonal responsive element site recognized by androgen receptor. Proc Natl Acad Sci U S A 1997; 94:5673.

15. Umekita Y, Hiipakka RA, Liao S. Rat and human maspins: structures, metastatic suppressor activity and mutation in prostate cancer cells. Cancer Lett 1997: 113: 87

16. Sheng S, Truong B, Fredrickson D, Wu R, Pardee AB, Sager R. Tissue-type plasminogen activator is a target of the tumor suppressor gene maspin. Proc Natl Acad Sci U S A 1998: 95:499-504.

17. Clarke SJ, Rivory LP. Clinical pharmacokinetics of docetaxel. Clin Pharmacokinet 1999: 36:99-114.

18. Lyseng-Williamson KA, Fenton C. Docetaxel: a review of its use in metastatic breast cancer. Drugs 2005: 65: 2513-2531.

19. Munkarah AR, Ali-Fehmi R, Jiang JZ, Elhammady E, Malone JM, Saed GM. The effects of combining docetaxel and cyclooxygenase-2 inhibitors on proliferation and apoptosis in epithelial ovarian cancer. Anticancer Drug 2007: 18: 889-896.

20. Supriatno, Harada K, Yoshida H, Sato M. Basic investigation on the development of molecular targeting therapy against cyclindependent kinase inhibitor p27Kip1 in head and neck cancer cells. Int J Onco 2005; 27: 627-35.

21. Rowinsky EK, Flood WA, Sartorius SE, Bowling KM, Ettinger DS. Phase I study of paclitaxel on a 3-hour schedule followed by carboplatin in untreated patients with stage IV non-small cell lung cancer. Invest New Drugs 1997:15: 129-138.

22. Amato SF, Swart JM, Berg M, Wanebo HJ, Mehta SR, Chiles TC. Transient stimulation of the c-Jun-NH2-terminal kinase/activator protein 1 pathway and inhibition of extracellular signal-regulated kinase are early effects in paclitaxel-mediated apoptosis in human B lymphoblasts. Cancer Res 1998; 58: 241-7.

23. Ling $\mathrm{YH}$, Tornos $\mathrm{C}$, Perez-Soler $\mathrm{R}$. Phosphorylation of Bcl-2 is a marker of $\mathrm{M}$ phase events and not a determinant of apoptosis. J Biol Chem 1998; 273: 1898491. 